\title{
Public Perception on Historical Landscape of Ethnic Immigrant Heritage in Heritage City of Baubau
}

\author{
Ray March Syahadat ${ }^{1 \bowtie}$, Nurhayati H.S. Arifin ${ }^{2}$, Hadi Susilo Arifin ${ }^{2}$ \\ ${ }^{1}$ Landscape Architecture Program, Graduate School of Bogor Agricultural University \\ ${ }^{2}$ Departement of Landscape Architecture, Bogor Agricultural University
}

Permalink/DOI: http://dx.doi.org/10.15294/komunitas.v6i2.3310

Received : July 2014; Accepted: August 2014; Published: September 2014

\begin{abstract}
As a one of the heritage cities in Indonesia, Baubau has many historical heritages which are not only created by local ethnics but also by immigrants. There are three historical landscapes created by the immigrants like China Town by Chinese, Waliabuku by Buginese, and Ngkaring-Ngkaring by Balinese. Until now, proper management to preserve the landscapes does not exist and it remains unknown whether this phenomenon is caused by the public perception who think that historical landscapes of immigrants as an unimportant heritage. The objective of this study is to investigate the public perception of historical landscapes that are created by immigrant in Baubau city as an heritage city in Indonesia. The results of survey show that the public regard all historical landscapes must be preserved. However, the landscapes created by the ethnic of Chinese have the lowest degree of public selection as compared to the ethnics of Bali and Bugis. The situation is triggered by the stereotype on the ethnic of Chinese which state that they tend to be more closed and reserved.
\end{abstract}

\begin{abstract}
Abstrak
Sebagai salah satu kota pusaka di Indonesia, Baubau memiliki banyak peninggalan sejarah bukan hanya yang dibentuk oleh etnis lokal, tetapi juga oleh etnis pendatang. Setidaknya terdapat tiga lanskap sejarah yang dibentuk oleh etnis pendatang yaitu lanskap pecinan oleh etnis Tionghoa, lanskap Waliabuku oleh etnis Bugis, dan lanskap Ngkaring-Ngkaring oleh etnis Bali. Sampai saat ini belum ada pengelolaan untuk melestarikan ketiga lanskap tersebut dan belum diketahui apakah fenomena ini dipengaruhi oleh persepsi masyarakat yang merasa lanskap peninggalan etnis pendatang tidaklah penting? Tujuan penelitian ini yaitu mengkaji persepsi masyarakat terhadap lanskap sejarah peninggalan etnis pendatang sebagai aset pusaka Kota Baubau sebagai kota pusaka Indonesia. Hasil yang diperoleh dari survei yang dilakukan, masyarakat umumnya menganggap seluruh lanskap sejarah harus dilestarikan tidak memandang apakah dibentuk oleh etnis lokal atau pendatang. Meskipun demikian, lanskap yang dibentuk oleh etnis Tionghoa memiliki derajat pemilihan paling rendah dari lanskap yang dibentuk etnis Bali dan Bugis. Hal ini disebabkan oleh adanya stereotip akibat karakter etnis Tionghoa yang dianggap masyarakat cenderung tertutup di Kota Baubau.
\end{abstract}

Keywords: Baubau City; heritage city; historical landscape; public partisipasion; stereotype

How to Cite: Syahadat, R.M., Arifin, N.H.S, \& Arifin, H.S. 2014. Public Perception on Historical Landscape of Ethnic Immigrant Heritage in Heritage City of Baubau. Jurnal Komunitas, 6(2):312-219. doi:http://dx.doi. org/10.15294/komunitas.v6i2.3310

(C) 2014 Semarang State University. All rights reserved

\footnotetext{
Corresponding author:

Address: Landscape Architecture Program, Graduate School of Bogor Agricultural University

J1 Meranti Kampus IPB Dramaga, Bogor, Indonesia 16680

Email :raymarch.syahadat@gmail.com
}

ISSN 2086-5465 


\section{INTRODUCTION}

Baubau city, Southeast Sulawesi Province, through Planning and Preservation Program Heritage Cities $\left(\mathrm{P}_{3} \mathrm{KP}\right)$ is set to be one of the ten prioritized heritage cities in Indonesia. One of the long-term goals of the program is the recognition of Indonesian heritage city as the world heritage. Baubau city itself is the former capital of the Kingdom and the Sultanate of Buton which has a lot of historical heritage and landscape. The historical landscapes in Baubau city not only were shaped by the local ethnic, but also by ethnic immigrants. This is what makes the heritage city of Baubau different from other cities, especially because of its diversity.

The team of heritage city has done an inventory and clustering of the heritage landscapes and assets based on the morphological characters which grow in every region but none of them is concerning on the heritage assets created by the ethnic immigrants (Drijen Penataan Ruang 2013: 150-170). The reasons behind this phenomenon remain unknown; whether the people of Baubau assume that heritage by ethnic immigrants is not important or there is any social conflict between the local people with the ethnic immigrants.

This study aims to investigate the public perception on the assets of the historical landscape of ethnic immigrant heritage in Baubau city as the heritage city of Indonesia. This study is based on the participation and perceptions on the issue of heritage conservation which has become a global issue since the late 2 oth century and proved to have significant value to the sustainability of urban heritage conservation program (Sarvazadeh and Abidin 2012: 214-225).

\section{METHODS}

The experiment was conducted in the City Baubau, Southeast Sulawesi Province in February and May 2014. The method used in this research was the search of history with the in-depth interviews and literature review, survey to the community using questionnaires, and also focus group discussion (FGD). The technique of extracting information was through in-depth interviews using the snowball technique referring to Rosyida and Nasdian (2011: 51-71). The survey to the public used a sample of 359 respondents with criteria Baubau City community who were $\geq 17$ years old. FGDs were conducted to investigate deeper on the phenomenon that occurred based on the results of in-depth interviews and community survey. FGD respondents consisted of nine representatives of the people with different backgrounds, such as, bureaucrats, cultural observers, entrepreneurs, academicians, immigrants, youth, students, and tourists.

\section{RESULTS AND DISCUSSION}

The three largest ethnic immigrants residing in the city Baubau live as neighbors. All three ethnic groups include the ethnic of Chinese in Chinatown landscape, the ethnic of Buginese in Waliabuku landscape, and the ethnic of Balinese in Ngkaring-Ngkaring landscape. Despite their gregarious neighbor, the interaction among those three ethnics with local ethnic ethnicity remains to be well-maintained.

The contact between Buton and China had existed since the days of pre-kingdom of Buton (Zahari 1977a: 28). Allegedly, the ethnic of Chinese in Baubau migrated gradually. The Chinatown in the coastal landscape of Baubau city was established around the 19th century or early 2oth century (Figure 1). The existence of a community in Chinatown was regulated by the Dutch. In Brugman Asyikin agreement on April 8, 1906, it was mentioned in article 22, paragraph 2 that "The existence of the Chinese people who live in Buton has become big because at that time, whenever the Dutch Guvermen requests any assistance, they should receive it just like with Guvermen Dutch" (Zahari 1977c : 94).

Just like any colonial cities built by the Dutch, east migrant resident occupied its own territory. Chinese people came to the City Baubau to look for economic opportunities and then stayed permanently around the settlement of the Dutch (Rabani 2010: 76-78). The place of residence where they lived then formed a distinctive special character such as character of Chinatowns in ot- 
her parts of Indonesia -in the form of a row of shop building (Dewi et al. 2005: 17-26). Currently, the shop houses in Chinatown in the city landscape of Baubau still maintain its authenticity and the age are estimated to have reached 100 years.

Usually, the Chinatown area is adjacent to the area which is inhabited by the ethnic of Pekojan Arabic (Suprihatin et al. 2009: 1-12). This is due to the policy of the Dutch government as stipulated in the regulations of Wijkenstelsel (Suryaningrum et al. 2009: 65-78). But in Baubau, Pekojan is not found because there is an emotional bond between the Arab community and the Sultanate of Buton so Arabic community can easily blend with the landscape of Buton Kraton. The impact of colonial settlement to the Chinese community, the Dutch community, and the local population in Baubau can be said as unique because there is no political and racial sentiments which eventually form the social stratification as found in the other cities of Indonesia. This interaction can sometime creates harmony and also dispute or tension (Basundoro 2012 : 1-13).

Bugis cultural center is located in Waliabuku (Figure 2). Annually, the city holds Padenda which is a harvest festival in the house of custom leader. The event is not only attended by the ethnic of Bugis in Waliabuku but also the entire family of South Sulawesi who live in Baubau city. The numbers of Buginese families in Waliabuku are approximately 70 families who generally work as rice and cocoa farmers. Generally, the ethnic of Buginese in Waliabuku live in a traditional house (Syarifuddin A March 23, 2014, personal communication). It is not known for sure since when Buginese began to settle in Baubau city because it is told that the relationship between Buginese (especially Buginese of Bone) and Buton has been existing for a long time. The relationship is not even merely a friendship but it is a close brotherhood (Zahari 1977b: 36). According

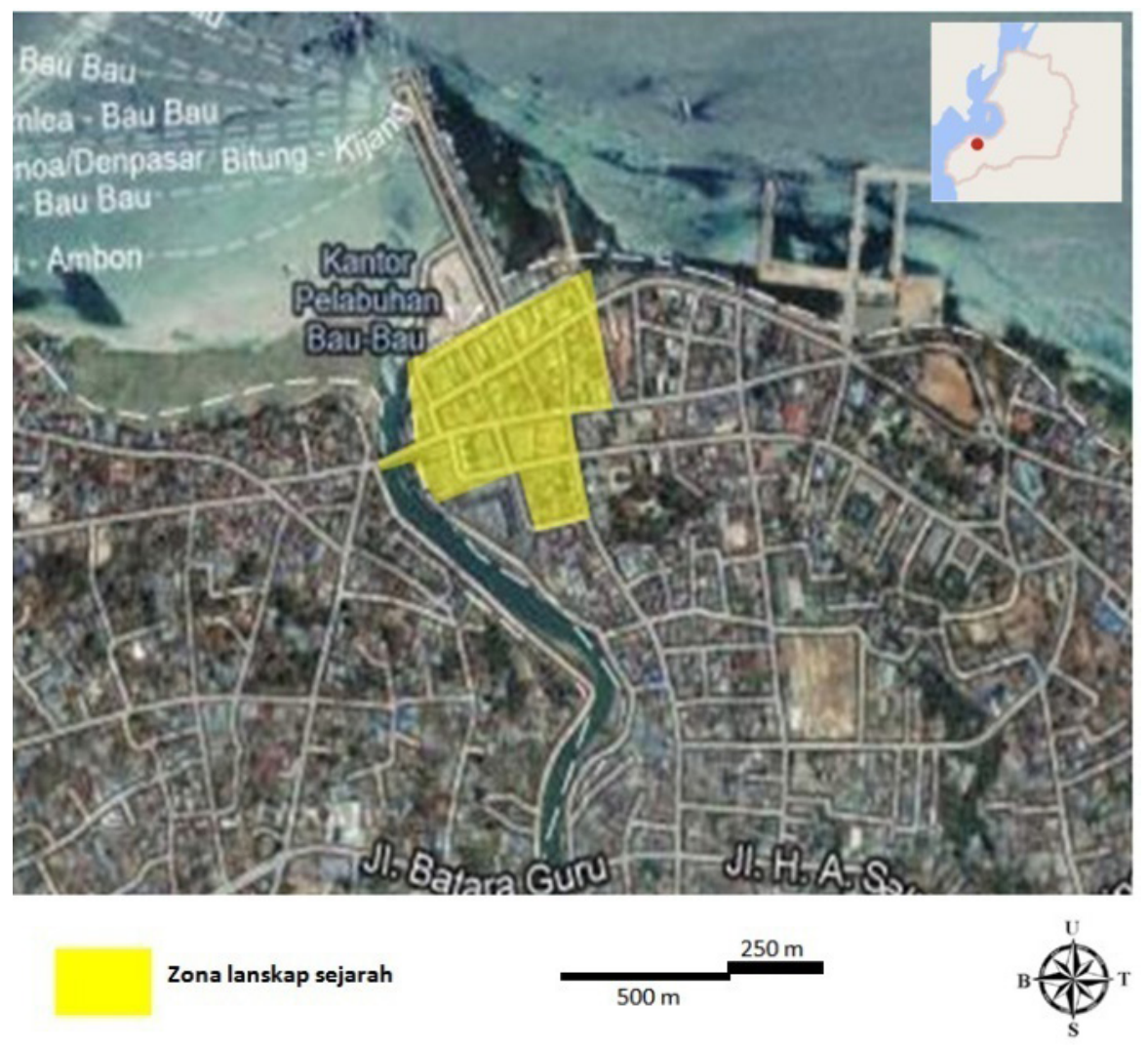

Figure 1. Chinatown Landscape 


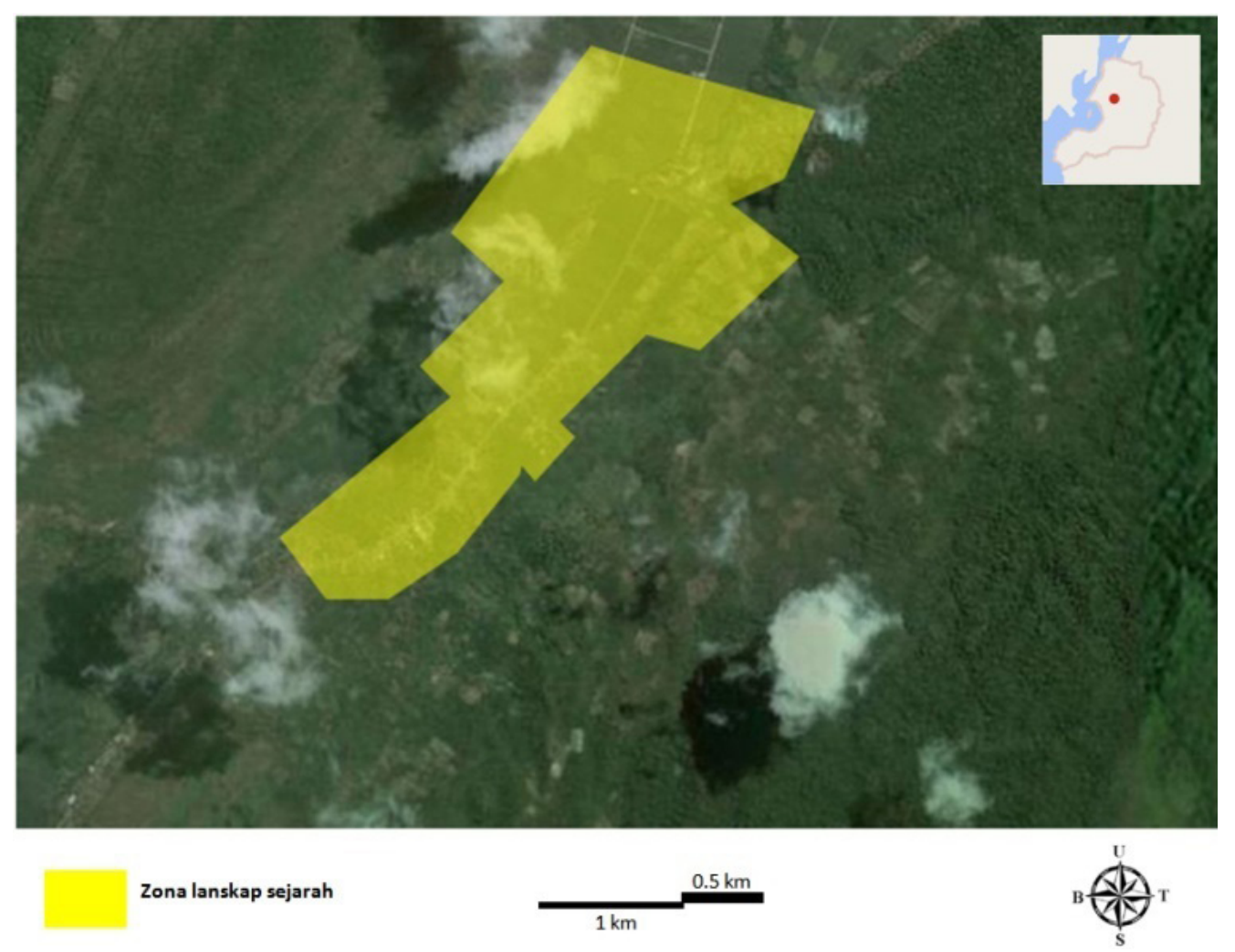

Figure 2. Waliabuku Landscape

to the obtained information, the biggest wave of migration of Buginese to Baubau occurred in 1960-1970s. Most ethnic of Buginese then worked as a tobacco merchant (Syarifuddin A March 23, 2014, personal communication).

The ethnic of Bugis in Liabuku live together with the ethnic of Liabuku, one of the local ethnic in Baubau city. The numbers of families of ethnic Liabuku are 50 households. Just like the ethnic of Bugis in Waliabuku, the ethnic of Liabuku also generally live in a traditional style house of Buton. Ethnic Liabuku itself has its own custom structure so that in Waliabuku there are two traditional chiefs who serve as the head of Buginese and Liabuku customs (Hiji L March 23, 2014, personal communication). This is what gives uniqueness to the landscape of Waliabuku. Moreover, these two ethnic groups live in harmony and some of them are tied by the marital relationship bond.

The ethnic of Balinese has been sett- ling down in Ngkaring-Ngkaring since 1978 through the transmigration program. There is information stating that Balinese themselves initiated coming to Buton to find fertile soil, and then made a proposal to the government. They were finally allowed to move. Other information states that they were called to expel the evil spirits in the region of Ngkaring-Ngkaring. It is said that this region was once a place where people died suddenly. Then after the Balinese arrived, the situation became peaceful (Coppenger 2011: 215). The ethnic of Balinese live as rice farmers and are also known to be good at making bricks. They form a landscape based on their typical Balinese culture in Ngkaring-Ngkaring (Figure 3).

The community life in NgkaringNgkaring is very harmonious and never encounter any significant conflict with the local population in Buton (Sukardi N February 27, 2014, personal communication). This statement is in accordance with what was reported by Ramadan (2012: 297) 


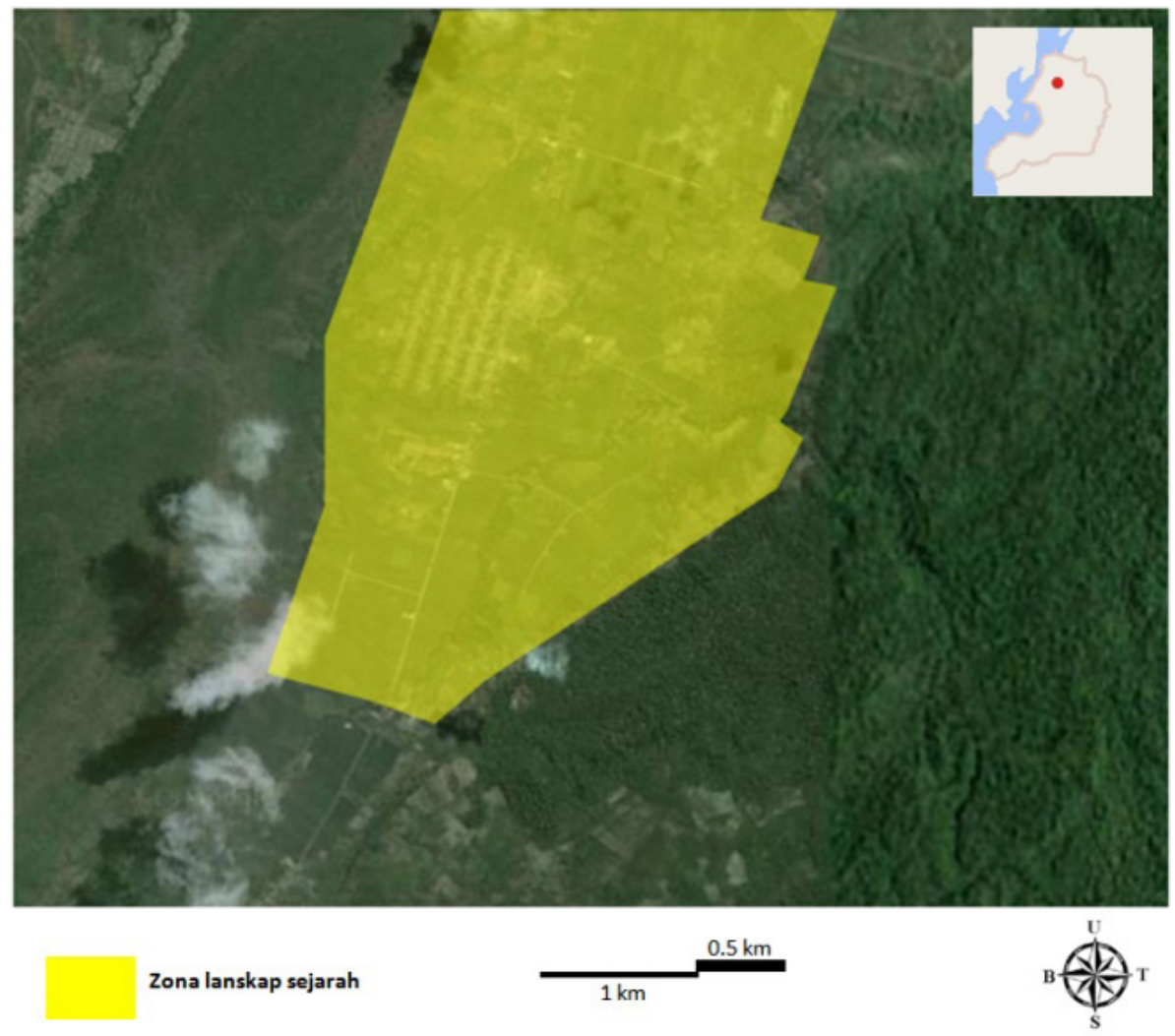

Figure 3. Ngkaring-Ngkaring Landscape

concerning on inter-ethnic relations in Baubau especially for the ethnic of immigrants. The study shows that there is no symptom which indicates the plurality of ethnicity, religion, and culture as a source of conflict in Buton.

The results of the community survey shows that almost all respondents consider Baubau City heritage must be preserved. Respondents also do not agree that heritage which must be preserved is only the heritage belonging to the ethnic of majority. However, the agreement percentages for the preservation of heritage belonging to ethnic immigrants is lower (Table 1 )

When respondents are asked about which ethnic landscape of migrant communities are worth to be preserved, the result shows that the landscape Waliabuku rank first, then followed by Ngkaring-Ngkaring landscape and the last landscape is Chinatown. However, more than half of the respondents consider that the three ethnic immigrant landscapes formed as a heritage asset of Baubau, should be well preserved (Figure 4).

FGDs are conducted in order to investigate further on the cause of the phenomenon that occurs in the community dealing with the existence of ethnic immigrants. The questions on the survey are repeated to the society representatives and the ans-

Table 1. Public perception of heritage conservation in the City Baubau

\begin{tabular}{lcc}
\hline Questions & \multicolumn{2}{c}{ Answers } \\
\hline Heritage should be preserved in the Baubau City & Disagree & Agree \\
Only the heritage of majority ethnic that must be preserved & $\mathbf{1} \%$ & $99 \%$ \\
Ethnic heritage of immigrants must also be preserved & $92 \%$ & $8 \%$ \\
\hline
\end{tabular}

UNNES JOURNRLS




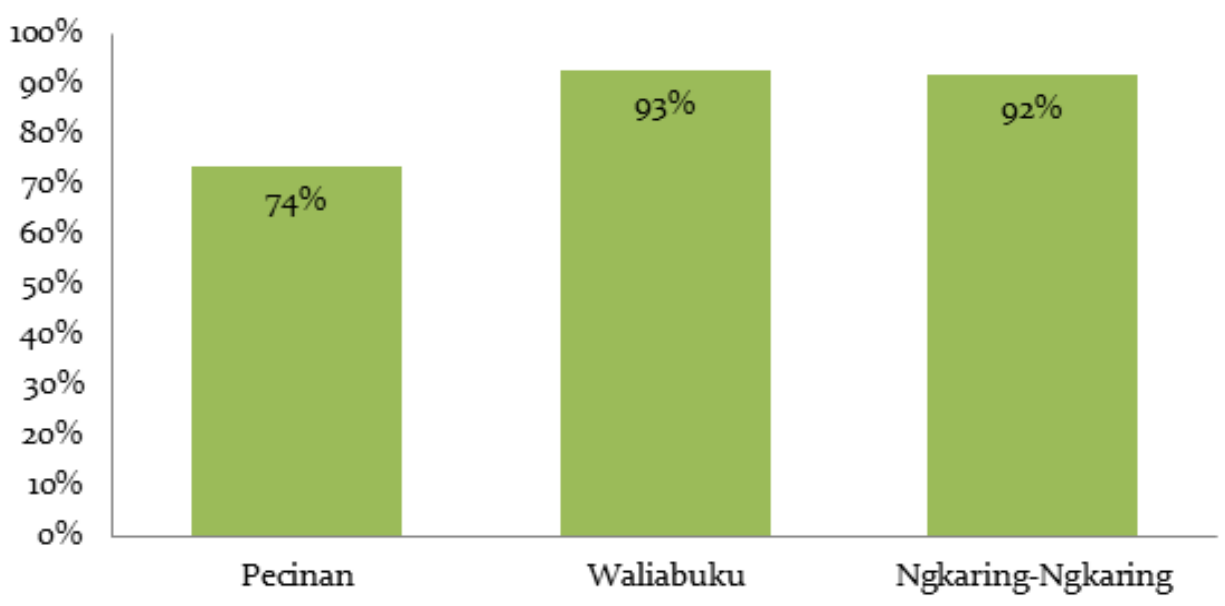

Figure 4. Percentage of public perceptions of the historical landscapes of ethnic immigrant heritage which are considered to be preserved

wers of FGD respondents are similar to the results of the survey of 359 respondents who generally regard the entire heritage must be preserved. The respondents are also asked to continue the survey by including the given percentage of the survey results; respondents say that one of the compelling reasons about the phenomenon is because the ethnic majority plays strong role in society. As a result, the community has a great pride to their culture than the culture belonging to the ethnic minorities especially newcomers or immigrants.

Baubau city community has always lived in harmony since the days of the Kingdom and the Sultanate of Buton. They are already accustomed to live together and respect the policy of ethnic roles. This situation is what makes inter-ethnic conflicts never happened. Previously in the Kingdom and the Sultanate of Buton, people were not only from one ethnicity but more than 30 ethnicities. The high diversity of ethnic causes the present scientists debating the real number of local ethnic in the Kingdom and the Sultanate of Buton.

Low selection of Chinatown landscape formed by the ethnic Chinese community is because of the stereotypes toward Chinese community in the Baubau City. This is in line with research conducted by Lestari (2007: 41-72) in Bali and Riyanti (2013: 5365) in Banjarnegara stating that stereotypes are often against the ethnic of Chinese.
The different stereotypes in the Baubau city based on the FGD responses is because Chinese people are very reserved so the local people feel less close to them.

Comparing with the ethnic of Balinese, although it can be said that they are one of the major ethnic immigrants who have newly come, Baubau people feel a better relationship with them. This is because the ethnic of Balinese is more open to the local people. Each year, they hold a religious ceremony in their landscape and it can be seen by everyone. Balinese and local ethnic work as farmers - often mutually share beneficial interaction. The ethnic of Balinese, for example, help controlling the boars in the local people farm.

The Chinese people also continue to implement their traditions such as Chinese New Year celebration and cap go meh. If in other areas, they usually have festive celebration and can be watched by the whole society, as reported by Fitriyani (2012: 73-81) in her study in Purbalingga, ethnic Chinese in Baubau generally have closed celebration. However, it is reported that they ever performed a celebration in their landscape that can be enjoyed by public. This closeness is what makes the emergence of stereotypes and misunderstandings exist, especially dealing with the inter-ethnic relations.

The landscape Waliabuku ranks first as the heritage landscape of ethnic immigrants that needs to be preserved. Although 
the annual tradition which is celebrated does not also involve the local community, but the people of Buton in Baubau City feel the emotional bond with the Buginese community. The history of Buton and Bugis stated earlier is a brotherhood relationship which can be seen clearly from the results of this study. Other things that cause such close relationship other than historical factor are the similar beliefs. And in Waliabu$\mathrm{ku}$, the ethnics who live there is not only the ethnic of Buginese but also ethnic of Liabu$\mathrm{ku}$ as one of the local ethnic.

In general, it can be said that what is disclosed by Lestari (2007: 41-72) that the more the ethnics are, the possibility of stereotypes can be justified. It also occurs not only on ethnic immigrants, even it can go against the fellow local ethnics, in this case the clash is between minority and majority as expressed by Tahara (2012: 75-97) on the research in Baubau city. However, there are values that can be learned from the people of Baubau despite the stereotypes which exist, but life must always be peaceful. It is also in line with the philosophy inherited during the Sultan Laelangi containing suggestions for mutual respect and protection and love toward each other (Ramadan 2012: 297-298).

From the obtained results, it can be said that the public perception of historical landscape of ethnic immigrants' heritage in Baubau city is influenced by stereotypes. However, the factors which influence the disapproval of some respondents are more because of the ignorance due to differences in the perspective of different cultures. As an asset, the historical landscape of ethnic immigrants should be preserved and should provide an education to the community in a way that is creative, innovative, and entertaining. The government of Baubau city through the $\mathrm{P}_{3} \mathrm{KP}$ can make a routine schedule of event on the historical landscape of ethnic immigrants, for example by conducting the celebration of holidays that can be enjoyed by whole community. The events held in historical landscape will not only be able to preserve them and educate the public, but also serve as a forum of inter- ethnic interaction, increase tourist attraction, and also improving the economy around the historical landscape.

\section{CONCLUSION}

Baubau city community generally considers the entire historical landscape as heritage assets that should be preserved regardless of whether they are formed by local ethnic or immigrants. However, the landscapes formed by the Chinese have the lowest public selection degree as compared to the landscapes formed by the ethnic of Buginese and Balinese. This circumstance is due to the lack of knowledge as a result of stereotypes against the ethnic of Chinese that are considered by community as a reserved people. Some routine activities on the historical landscape of ethnic heritage of immigrants are also recommended to hold in order to preserve the historical landscape heritage, to educate the public, to be the triggering place of interaction among ethnicities, to increase tourist attraction, and also to improve the economy around the historical landscape.

\section{REFERENCES}

Basundoro, P. 2012. Penduduk dan Hubungan antar Etnis di Kota Surabaya pada Masa Kolonial. Paramitha. 22(1): 1-13.

Coppenger, C. 2011. The mysteries of the islands of $\mathrm{Bu}$ ton according to the old men and me. San Diego: Aventine Pr.

Dewi, A., Antariksa, Soesanto, S. 2005. Pengaruh Kegiatan Berdagang terhadap Pola Ruang-Dalam Bangunan Rumah-Toko di Kawasan Pecinan Kota Malang. Dimensi Teknik Arsitektur. 33(1): 17-26.

Dirjen Penataan Ruang. 2013. Pelaksanaan program penataan dan pelestarian kota pusaka Kota Baubau. Jakarta: Dirjen Penataan Ruang.

Fitriyani, R. 2012. Peranan Paguyuban Tionghoa Purbalingga dalam Pelestarian Tradisi Cap Go Meh. Komunitas. 4(1): 73-81.

Lestari, P. 2007. Stereotip dan Kompetensi Komunikasi Bisnis Antarbudaya Bali dan Cina. Jurnal Ilmu Komunikasi. 4(1): 41-72.

Rabani, L.O. 2010. Kota-kota pantai di Sulawesi Tenggara. Yogyakarta: Penerbit Ombak.

Ramadhan, S. 2012. Konflik sosial dan relasi antar etnik. In: Darmawan, Y., Mu'min, M (Ed). 2012. Negeri seribu benteng: lima abad dinamika di Kota Baubau, Baubau: RESPECT.

Riyanti, P. 2013. Relasi Sosial Pedagang Etnis Cina dan 
Etnis Jawa di Pasar Tradisional. Komunitas. 5(1): 53-65.

Rosyida, I., Nasdian, F.T. 2011. Partisipasi Masyarakat dan Stakeholder dalam Penyelenggaraan program Corporate Social Responsibility (CSR) dan Dampaknya terhadap Komunitas Perdesaan. Sodality. 5(1): 51-71.

Sarvazadeh, S.K., Abidin, S.Z. 2012. Problematic Issues of Citizens' Participation on Urban Heritage Conservation in The Historic Cities of Iran. Procedia - Social and Behavioral Sciences. 50(2012): 214-225.

Suprihatin, A., Antariksa, Meidiana, C. 2009. Pelestarian Lingkungan dan Bangunan Kuno di Kawasan Pekojan Jakarta. Jurnal Tata Kota dan Daerah. 1(1): 1-12.

Suryaningrum, S., Antariksa, Usman, F. 2009. Pelestarian Kawasan Pecinan Kota Bogor. Arsitektur
e-Journal. 2(1): 65-78.

Tahara, T. 2012. Reproduksi Stereotip Orang Katobengke dalam Sturuktur Masyarakat Buton. Antropologi Indonesia. 33(2): 75-97

Zahari, A.M. 1977 . Sejarah dan adat Fiy Darul Butuni (Buton) I. Jakarta: Proyek Pengembangan Media Kebudayaan Departemen Pendidikan dan Kebudayaan.

Zahari, A.M. 1977'. Sejarah dan adat Fiy Darul Butuni (Buton) II. Jakarta: Proyek Pengembangan Media Kebudayaan Departemen Pendidikan dan Kebudayaan.

Zahari, A.M. $1977^{c}$. Sejarah dan adat Fiy Darul Butuni (Buton) II. Jakarta: Proyek Pengembangan Media Kebudayaan Departemen Pendidikan dan Kebudayaan. 